Article

\title{
Changes in Weight and Nutritional Habits in Adults with Obesity during the "Lockdown" Period Caused by the COVID-19 Virus Emergency
}

\author{
Marianna Pellegrini ${ }^{1}$, Valentina Ponzo ${ }^{1, *}$, Rosalba Rosato ${ }^{2}$, Elena Scumaci ${ }^{1}$, Ilaria Goitre ${ }^{1}$, \\ Andrea Benso ${ }^{1}$, Sara Belcastro ${ }^{1}$, Chiara Crespi ${ }^{1}$, Franco De Michieli ${ }^{1,3}$, Ezio Ghigo ${ }^{1,3}$, \\ Fabio Broglio ${ }^{1,3}$ and Simona Bo ${ }^{1,3, * \text { (D) }}$ \\ 1 Department of Medical Sciences, University of Torino, c.so AM Dogliotti 14, 10126 Torino, Italy; \\ marianna.pellegrini@unito.it (M.P.); elena.scumaci@libero.it (E.S.); ilaria.goitre@libero.it (I.G.); \\ andrea.benso@unito.it (A.B.); sara.belcastro@unito.it (S.B.); chiaracrespi@hotmail.it (C.C.); \\ franco.demichieli@unito.it (F.D.M.); ezio.ghigo@unito.it (E.G.); fabio.broglio@unito.it (F.B.) \\ 2 Department of Psychology, University of Torino, c.so AM Dogliotti 14, 10126 Torino, Italy; \\ rosalba.rosato@unito.it \\ 3 Diabetes and Metabolic Diseases Clinic, "Città della Salute e della Scienza" Hospital of Torino, \\ 10126 Torino, Italy \\ * Correspondence: valentina.ponzo@unito.it (V.P.); simona.bo@unito.it (S.B.); Tel.: +39-0116336036 (S.B.)
}

Received: 25 May 2020; Accepted: 3 July 2020; Published: 7 July 2020

\begin{abstract}
Our aim is evaluating the changes in weight and dietary habits in a sample of outpatients with obesity after 1 month of enforced lockdown during the COVID-19 pandemic in Northern Italy. In this observational retrospective study, the patients of our Obesity Unit were invited to answer to a 12-question multiple-choice questionnaire relative to weight changes, working activity, exercise, dietary habits, and conditions potentially impacting on nutritional choices. A multivariate regression analysis was performed to evaluate the associations among weight/BMI changes and the analyzed variables. A total of 150 subjects (91.5\%) completed the questionnaire. Mean self-reported weight gain was $\approx 1.5 \mathrm{~kg}(p<0.001)$. Lower exercise, self-reported boredom/solitude, anxiety/depression, enhanced eating, consumption of snacks, unhealthy foods, cereals, and sweets were correlated with a significantly higher weight gain. Multiple regression analyses showed that increased education (inversely, $\beta=-1.15 ; 95 \% \mathrm{CI}-2.13,-0.17, p=0.022)$, self-reported anxiety/depression $(\beta=1.61 ; 0.53$, $2.69, p=0.004)$, and not consuming healthy foods $(\beta=1.48 ; 0.19,2.77, p=0.026)$ were significantly associated with increased weight gain. The estimated direct effect of self-reported anxiety/depression on weight was $2.07 \mathrm{~kg}(1.07,3.07, p<0.001)$. Individuals with obesity significantly gained weight 1 month after the beginning of the quarantine. The adverse mental burden linked to the COVID-19 pandemic was greatly associated with increased weight gain.
\end{abstract}

Keywords: COVID-19 infection; dietary habits; lockdown; obesity

\section{Introduction}

The pandemic of the coronavirus SARS-CoV-2 (COVID-19) has caused significant disruption in everyday lifestyle. In Italy, at the beginning of March, an important growth in infections and deaths was observed [1]; the whole country became a protected zone, with severe restrictive national measures, such as the closure of all activities not considered essential, including schools/university, sport activities, shops, and factories [2,3]. People had to stay at home and were only allowed to go out to buy food or for health reasons; all working activities were suspended or turned into smart working at home, except for essential activities (health workers, food supply and sale, cleaning of cities, and police, etc.). 
Therefore, since the 10th of March, 2020, the month of the start of the "lockdown", millions of Italians were forced to remain at home. This enforced quarantine can have a heavy psychological impact, above all among persons with obesity who are already at risk of social isolation and experiencing higher rates of depression [4]. The mental health burden during the COVID-19 outbreak has been evaluated by a few studies, and an increased rate of anxiety disorder, depressive symptoms, perceived stress, post-traumatic stress disorder, and poor sleep quality has been reported [5-10]. Usual lifestyle habits have been heavily disrupted by the mandatory stay-at-home orders, which may result in important behavior changes, particularly dietary habits, in this kind of natural experiment, "forced" by an unpredictable emergency [11]. The rise in unstructured time might induce overeating and increase screen time. Furthermore, social isolation might worse lifestyle behaviors with enhanced sedentarism, as well as decreased outdoor time and increased weight gain [12]. It has been hypothesized that the increased out-of-school time may exacerbate the weight gain of children in a similar way to summer recess [13]. No other data about the effects of quarantine in adult individuals with obesity are currently available.

The objective of the present observational study was to evaluate the changes in weight and dietary habits in a sample of individuals with obesity attending our Obesity Unit after 1 month of enforced lockdown.

\section{Materials and Methods}

This was an observational retrospective study. All the patients of the Obesity Unit of the Diabetes and Metabolic Diseases Clinic of the Città della Salute e della Scienza Hospital of Torino were enrolled. We included in the study all the patients who currently attend the weight loss program. In our unit, we take care of patients with BMI $>30 \mathrm{~kg} / \mathrm{m}^{2}$ and $<45 \mathrm{~kg} / \mathrm{m}^{2}$, aged 18-75 years. Dropouts (i.e., those who do not attend the scheduled appointment and either do not answer a call or declare that they no longer want to participate in the program) were excluded from the study.

\subsection{Weight Loss Program}

Our patients followed a 12-month multidisciplinary weight loss program that included at least six meetings. Supplementary visits could be scheduled in specific cases, such as the prescription of drugs or a very-low-calorie diet. During the first appointment, the patients received two group sessions (one by trained nurses who welcomed participants, evaluated the motivation, and discussed their strengths, weaknesses, opportunities, and one of nutritional education by dieticians) and individual visits with the endocrinologists, the psychologists and the dieticians. During follow-up, participants were initially visited by dieticians and endocrinologists every month and, after the first 90 days, every 3 months, with supplementary visits in case of specific needs.

All patients received verbal and written dietary, exercise, and behavior recommendations. A personalized diet was prescribed according to the Mediterranean diet (45-55\% carbohydrates, $<10 \%$ sugars, $30 \%$ fats, $<10 \%$ saturated fats, $15-25 \%$ proteins, and $20-30 \mathrm{~g}$ fiber) with a $500-1000 \mathrm{kcal}$ energy restriction, based on the individual usual assumption and caloric needs. Patients were asked to weigh themselves every day.

A moderate exercise, such as at least $150 \mathrm{~min} /$ week of brisk walking plus $30 \mathrm{~min} /$ week of exercise against resistance, was prescribed and a leaflet on examples of home exercises was given to all patients. Psychologists specialized in obesity treatment screened all attenders during the first visit to evaluate the need for further individual sessions for selected patients during the weight-loss program; a group session about motivation, how to recognize and manage emotional eating, relapse prevention, and self-manage social gatherings was delivered by the psychologists during the second visit.

\subsection{Questionnaire}

The research team developed a series of items which were then grouped and prioritized, based on a review of the literature, the feedbacks obtained during our group sessions about patients' 
difficulties in diet maintenance, and a consultation with clinical experts. A 12-question multiple-choice questionnaire was prepared. A cognitive debriefing of the questionnaire was performed with 10 patients selected using the method of purposive sampling. Interview content was analyzed informally. After providing informed consent, patients completed the questionnaire; a psychologist (ES), experienced at interviewing, conducted individual telephone interviews with patients with the aim to assess the readability of the questions and the acceptability of the questionnaire. Two questions, which were deemed unclear, were then reformulated.

The questions were relative to the weight before and after 1 month of lockdown and working activity and exercise during quarantine, with many items related to the changes in dietary habits and the conditions potentially impacting on nutritional choices. Exercise during the lockdown was considered as practicing at home (indoor exercise bike, treadmill, and resistance training) or jogging/running around the house, given that it was not possible either to participate in organized sports or perform other outdoor activities. A snack was considered as every eating occasion between main meals. According to our weight loss program, patients should weigh themselves every day with the same scale. They were asked to report their weight on the 11th of March and at the date of the questionnaire compilation (see below). Night eating syndrome was diagnosed in the presence of recurrent episodes of night eating, as manifested by eating after awakening from sleep or by excessive food consumption after the evening meal, with awareness and recall of the eating, without association with effects of medications, another medical or mental disorder, or external influences (such as changes in the individual's sleep-wake cycle or local social norms), in line with the DSM-5 criteria [14]. Weight cycling was defined in the presence of $>2$ weight-loss cycles followed by weight regain.

A dedicated researcher contacted the patients by phone and explained to the patients how to fill out the questionnaire. The questionnaire was sent by e-mail on the 14th of April, 2020. The patients completed it in autonomy and returned it between the 14th of April and the 21st of April. Patients were strongly requested to be truthful and to answer carefully in order to ensure the quality of the survey. In 15 cases, patients were unable to fill in the questionnaire by email and completed it by telephone interview with the same researcher.

Clinical and sociodemographic data referring to the first ambulatory visit were extracted from the clinical records. At the first visit, the following anthropometric measurements were assessed: weight (measured with the participant wearing light clothes and no shoes to the nearest $0.1 \mathrm{~kg}$ by a mechanical column scale, SECA model 711, Hamburg, Germany), height (measured to the nearest $0.1 \mathrm{~cm}$ with a Stadiometer, SECA 220 measuring rod, Hamburg, Germany), waist and neck circumferences (measured by a plastic tape meter respectively at the umbilicus level or under the cricoid cartilage).

\subsection{Ethical Aspects}

Each patient gave his/her verbal informed consent to participate to the study. The study protocol was approved by the Ethics Committee of the Città della Salute e della Scienza Hospital of Turin.

\subsection{Statistical Analyses}

Within-group weight and BMI variations were analyzed by $t$-test for paired samples. The changes in weight and BMI (values after 1-month of lockdown minus values before quarantine) did not show a normal distribution. Differences in weight/BMI changes were analyzed by Mann-Whitney test (two groups) or by Kruskal-Wallis test (three groups). A multiple regression model was performed to evaluate the association among weight/BMI changes and the variables which resulted significantly different between the various categories. A regression path model was applied to test the hypothesis that not healthy food choice could mediate the effects of self-perceived anxiety/depression on weight gain.

\section{Results}

A total of 164 patients were invited to participate in the survey; 150 participants completed the questionnaires and were included in the analysis, while 14 (8.5\%) either refused to participate, were not 
reachable, or provided incomplete answers to the questionnaire. The baseline characteristics of the participants are described in Table 1 and did not significantly differ from those of non-participants (data not shown). The mean duration of the attendance at our Obesity Unit was 6.7 months (Table 1).

Table 1. Clinical characteristics of participants before and after the lockdown period.

\begin{tabular}{|c|c|c|}
\hline & Mean or $\%$ & SD \\
\hline Age (years) & 47.9 & 16.0 \\
\hline Males (\%) & 22.7 & \\
\hline Living alone $(\%)$ & 49.3 & \\
\hline Not working/retired $(\%) *$ & 40.7 & \\
\hline Active smokers (\%) & 16.0 & \\
\hline \multicolumn{3}{|l|}{ Alcohol consumption: } \\
\hline Abstainers $(\%)$ & 88.7 & \\
\hline$<30 \mathrm{~g} /$ day alcohol (\%) & 11.3 & \\
\hline Secondary schools/graduation (\%) & 62.0 & \\
\hline Weight cycling $(\%)$ & 53.3 & \\
\hline Night eating $(\%)$ & 12.0 & \\
\hline \multicolumn{3}{|c|}{ Anthropometric values at the first ambulatory visit } \\
\hline Weight $(\mathrm{kg})$ & 97.8 & 16.3 \\
\hline $\operatorname{BMI}\left(\mathrm{kg} / \mathrm{m}^{2}\right)$ & 36.6 & 4.5 \\
\hline Waist circumference $(\mathrm{cm})$ & 113.8 & 11.8 \\
\hline Neck circumference (cm) & 37.4 & 3.7 \\
\hline \multicolumn{3}{|l|}{ Before the lockdown-period ${ }^{* *}$} \\
\hline Weight $(\mathrm{kg})^{1}$ & 92.0 & 17.0 \\
\hline BMI $\left(\mathrm{kg} / \mathrm{m}^{2}\right)$ & 34.4 & 4.9 \\
\hline Months of outpatient follow-up & 6.7 & 3.2 \\
\hline \multicolumn{3}{|l|}{ After the lockdown-period ** } \\
\hline Weight $(\mathrm{kg})$ & 93.5 & 17.5 \\
\hline Delta weight $(\mathrm{kg})$ & $+1.51(-7.0+10.0)^{\S}$ & \\
\hline BMI $\left(\mathrm{kg} / \mathrm{m}^{2}\right)$ & 35.0 & 5.2 \\
\hline Delta BMI $\left(\mathrm{kg} / \mathrm{m}^{2}\right)$ & $+0.58(-2.72+4.36)^{\S}$ & \\
\hline
\end{tabular}

* this category included: $21.3 \%$ unemployed; $36.1 \%$ housewives; $37.7 \%$ retired; $4.9 \%$ students. ${ }^{* *}$ self-reported weight; data collected by questionnaire. $\$$ (range).

On average, during the lockdown period, self-reported weight and BMI significantly increased by $1.51 \mathrm{~kg}\left(p<0.001\right.$ by $t$-test for paired samples) and $0.58 \mathrm{~kg} / \mathrm{m}^{2}(p<0.001)$, respectively.

The answers to the questionnaire are shown in Table 2. Most individuals either did not exercise or reduced their level of physical activity, and a great number of unhealthy nutritional behaviors were evident.

The changes in weight and BMI according to those answers are shown in Table 3. A significantly higher weight and BMI increase was evident in individuals with lower education, who reported lower exercise, self-reported boredom/solitude, anxiety/depression, enhanced eating, and consumption of unhealthy foods, snacks, cereals, and sweets. 
Table 2. Answers to the Questions of the Questionnaire.

\begin{tabular}{|c|c|c|c|c|c|}
\hline$\%$ & Answers & Question & $\%$ & Answers & Question \\
\hline 7.3 & $\begin{array}{l}\text { Yes, I habitually used those services } \\
\text { even before the quarantine }\end{array}$ & \multirow{4}{*}{$\begin{array}{l}\text { During the lockdown period, have you used } \\
\text { food delivery services? }\end{array}$} & 33.3 & Home working & \multirow{4}{*}{ My current working situation is: } \\
\hline 6 & $\begin{array}{l}\text { Yes, I started using them during the } \\
\text { quarantine }\end{array}$ & & 15.3 & I still go to workplace & \\
\hline 8.7 & $\begin{array}{l}\text { I didn't use them during quarantine, } \\
\text { but I used them before }\end{array}$ & & 16.7 & $\begin{array}{l}\text { I haven't been working since the } \\
\text { beginning of the quarantine }\end{array}$ & \\
\hline 78 & $\begin{array}{l}\text { No, I did use them neither during } \\
\text { quarantine, nor before }\end{array}$ & & 34.7 & Unemployed/retired before quarantine & \\
\hline 28 & I don't consume snacks usually & \multirow{4}{*}{$\begin{array}{l}\text { During the lockdown period, the number of } \\
\text { snacks that you consume in a day: }\end{array}$} & 32.6 & I never practice exercise & \multirow{4}{*}{$\begin{array}{l}\text { During the quarantine period, the } \\
\text { exercise that you have practiced: }\end{array}$} \\
\hline 11.3 & is less than before quarantine & & 46.7 & is less than before quarantine & \\
\hline 28 & is the same as before quarantine & & 10 & is the same as before quarantine & \\
\hline 32.7 & is more than before quarantine & & 10.7 & is more than before quarantine & \\
\hline 2.7 & I don't consume those foods usually & \multirow{4}{*}{$\begin{array}{l}\text { During the lockdown period, your } \\
\text { consumption of cereals (pasta, rice, other.): }\end{array}$} & 13.3 & No, I have maintained my eating habits & \multirow{4}{*}{$\begin{array}{l}\text { Have you changed eating habits } \\
\text { during the lockdown period? }\end{array}$} \\
\hline 16 & is less than before quarantine & & 34 & Not too much, with a few exceptions & \\
\hline 53.3 & is the same as before quarantine & & 40 & I eat more than before quarantine & \\
\hline 28 & is more than before quarantine & & 12.7 & I eat less than before quarantine & \\
\hline 0.7 & I don't consume those foods usually & \multirow{5}{*}{$\begin{array}{l}\text { During the lockdown period, your } \\
\text { consumption of sources of protein (meat, } \\
\text { fish, eggs, cheese, legumes): }\end{array}$} & 32.7 & More time for cooking & \multirow{5}{*}{$\begin{array}{l}\text { Which of the following conditions } \\
\text { mainly impact on your eating habits? } \\
\text { (you can choose more than } 1 \text { option) }\end{array}$} \\
\hline 18 & is less than before quarantine & & 21.3 & $\begin{array}{l}\text { Greater familial conviviality caused by } \\
\text { forced domestic cohabitation }\end{array}$ & \\
\hline 54 & is the same as before quarantine & & 36 & Boredom/solitude & \\
\hline 27.3 & is more than before quarantine & & 34.7 & Anxiety/depression & \\
\hline 0.7 & I don't consume those foods usually & & 19.3 & Continuous availability of food & \\
\hline 18 & is less than before quarantine & \multirow{3}{*}{$\begin{array}{l}\text { During the lockdown period, your } \\
\text { consumption of fruit and vegetables: }\end{array}$} & 16 & $\begin{array}{l}\text { I consume/prepare more healthy foods, } \\
\text { paying attention to the seasoning }\end{array}$ & \multirow{3}{*}{$\begin{array}{l}\text { During the lockdown period, the } \\
\text { healthy foods that you } \\
\text { prepare/consume: }\end{array}$} \\
\hline 54 & is the same as before quarantine & & 56 & $\begin{array}{l}\text { I have not changed habits with respect to } \\
\text { the type of food }\end{array}$ & \\
\hline 27.3 & is more than before quarantine & & 28 & $\begin{array}{l}\text { I don't pay attention to how healthy a } \\
\text { food is. I consume/prepare foods that } \\
\text { give me satisfaction }\end{array}$ & \\
\hline
\end{tabular}


Table 2. Cont

\begin{tabular}{|c|c|c|c|c|c|}
\hline$\%$ & Answers & Question & $\%$ & Answers & Question \\
\hline 16 & I don't consume those foods usually & \multirow{4}{*}{$\begin{array}{l}\text { During the lockdown period, your } \\
\text { consumption of sweets: }\end{array}$} & 17.3 & $\begin{array}{l}\text { I buy/consume more frozen/canned food } \\
\text { than before quarantine }\end{array}$ & \multirow{4}{*}{$\begin{array}{l}\text { During the quarantine period, the } \\
\text { type of food that you } \\
\text { prepare/consume: }\end{array}$} \\
\hline 12 & is less than before quarantine & & 62 & I haven't changed habits with respect to & \\
\hline 22 & is the same as before quarantine & & & the type of food & \\
\hline 50 & is more than before quarantine & & 20.7 & $\begin{array}{l}\text { I buy/consume more fresh food than } \\
\text { before quarantine (including fruit and } \\
\text { vegetables) }\end{array}$ & \\
\hline
\end{tabular}


Table 3. Changes in weight and BMI after 1-month lockdown according to different characteristics.

\begin{tabular}{|c|c|c|c|c|c|}
\hline Characteristics & Number & Weight Change (kg) & $p^{*}$ & BMI Change $\left(\mathrm{kg} / \mathrm{m}^{2}\right)$ & $p^{*}$ \\
\hline \multicolumn{6}{|l|}{ Gender } \\
\hline Male & 34 & +1.30 & & +0.46 & \\
\hline Female & 116 & +1.57 & 0.38 & +0.62 & 0.75 \\
\hline \multicolumn{6}{|l|}{ Age class (years) } \\
\hline$\leq 50$ & 76 & +1.24 & & +0.47 & \\
\hline$>50$ & 74 & +1.80 & 0.68 & +0.70 & 0.48 \\
\hline \multicolumn{6}{|l|}{ Living alone } \\
\hline No & 76 & +1.84 & & +0.71 & \\
\hline Yes & 74 & +1.17 & 0.50 & +0.45 & 0.49 \\
\hline \multicolumn{6}{|l|}{ Not working/retired } \\
\hline No & 61 & +1.64 & & +0.65 & \\
\hline Yes & 89 & +1.42 & 0.90 & +0.54 & 0.79 \\
\hline \multicolumn{6}{|l|}{ Active smokers } \\
\hline No & 126 & +1.50 & & +0.58 & \\
\hline Yes & 24 & +1.57 & 0.71 & +0.59 & 0.78 \\
\hline \multicolumn{6}{|l|}{ Secondary schools/graduation } \\
\hline No & 57 & +2.53 & & +0.98 & \\
\hline Yes & 93 & +0.89 & 0.013 & +0.34 & 0.012 \\
\hline \multicolumn{6}{|l|}{ Weight cycling } \\
\hline No & 70 & +1.14 & & +0.46 & \\
\hline Yes & 80 & +1.84 & 0.23 & +0.69 & 0.27 \\
\hline \multicolumn{6}{|l|}{ Night eating } \\
\hline No & 132 & +1.34 & & +0.51 & \\
\hline Yes & 18 & +2.75 & 0.11 & +1.10 & 0.12 \\
\hline \multicolumn{6}{|l|}{ During the lockdown period: } \\
\hline \multicolumn{6}{|l|}{ Still working at workplace } \\
\hline No & 127 & +1.51 & & +0.58 & \\
\hline Yes & 23 & +1.50 & 0.61 & +0.57 & 0.54 \\
\hline \multicolumn{6}{|l|}{ Exercise levels } \\
\hline None or lower & 119 & +1.85 & & +0.70 & \\
\hline Usual or higher & 31 & +0.23 & 0.012 & +0.13 & 0.011 \\
\hline \multicolumn{6}{|l|}{ Change in dietary habits ${ }^{* *}$} \\
\hline No/minimal changes & 71 & +0.86 & & +0.34 & \\
\hline Increased eating & 60 & +3.14 & & +1.20 & \\
\hline Decreased eating & 19 & -1.17 & $<0.001$ & -0.45 & $<0.001$ \\
\hline \multicolumn{6}{|l|}{$\begin{array}{l}\text { Conditions impacting on eating habits } \\
\text { Boredom/solitude }\end{array}$} \\
\hline No & 96 & +1.03 & & +0.40 & \\
\hline Yes & 54 & +2.37 & 0.012 & +0.91 & 0.011 \\
\hline \multicolumn{6}{|l|}{ Anxiety/depression } \\
\hline No & 93 & +0.49 & & +0.20 & \\
\hline Yes & 57 & +3.18 & $<0.001$ & +1.21 & $<0.001$ \\
\hline \multicolumn{6}{|l|}{ Food availability } \\
\hline No & 121 & +1.31 & & +0.51 & \\
\hline Yes & 29 & +2.37 & 0.16 & +0.89 & 0.16 \\
\hline \multicolumn{6}{|l|}{ Consuming healthy foods ** } \\
\hline No & 42 & +3.70 & & +1.42 & \\
\hline Not changed & 84 & +1.08 & & +0.41 & \\
\hline Yes & 24 & -0.81 & $<0.001$ & -0.30 & $<0.001$ \\
\hline \multicolumn{6}{|l|}{ Type of food ** } \\
\hline More frozen/canned foods & 26 & +2.21 & & +0.85 & \\
\hline Not changed & 93 & +1.22 & & +0.49 & \\
\hline More fresh foods & 31 & +1.80 & 0.08 & +0.64 & 0.08 \\
\hline
\end{tabular}


Table 3. Cont.

\begin{tabular}{|c|c|c|c|c|c|}
\hline Characteristics & Number & Weight Change (kg) & $p^{*}$ & BMI Change $\left(\mathrm{kg} / \mathrm{m}^{2}\right)$ & $p^{*}$ \\
\hline \multicolumn{6}{|l|}{ Use of food delivery } \\
\hline No & 130 & +1.40 & & +0.53 & \\
\hline Yes & 20 & +2.25 & 0.33 & +0.90 & 0.25 \\
\hline \multicolumn{6}{|l|}{ Number of snacks } \\
\hline None or lower & 59 & +0.55 & & +0.20 & \\
\hline Usual or higher & 91 & +2.14 & 0.007 & +0.83 & 0.005 \\
\hline \multicolumn{6}{|l|}{ Cereal consumption } \\
\hline None or lower & 28 & -0.54 & & -0.19 & \\
\hline Usual or higher & 122 & +1.98 & $<0.001$ & +0.76 & $<0.001$ \\
\hline \multicolumn{6}{|l|}{ Protein consumption } \\
\hline None or lower & 28 & +1.42 & & +0.54 & \\
\hline Usual or higher & 122 & +1.53 & 0.99 & +0.59 & 0.95 \\
\hline \multicolumn{6}{|l|}{ Fruit/vegetable consumption } \\
\hline None or lower & 28 & +1.62 & & +0.63 & \\
\hline Usual or higher & 122 & +1.49 & 0.57 & +0.57 & 0.58 \\
\hline \multicolumn{6}{|l|}{ Sweet consumption } \\
\hline None or lower & 42 & -0.36 & & -0.14 & \\
\hline Usual or higher & 108 & +2.24 & $<0.001$ & +0.86 & $<0.001$ \\
\hline
\end{tabular}

${ }^{*} p$ by Mann-Whitney test; ${ }^{* *} p$ by Kruskal-Wallis test.

The increased consumption of snacks, cereals, and sweets were all highly correlated $(p<0.001$ by the chi-square test). By assessing their individual association with both weight and BMI changes in a multiple regression model, after adding education and exercise level, self-reported boredom/solitude, and anxiety/depression, only sweets consumption was significantly associated with weight/BMI changes. Then, a multiple regression analysis was run, with the inclusion of all the variables significantly associated with increased weight and BMI, except cereals and snacks consumption (Table 4). No multicollinearity between variables included in the multivariate analysis was found, since all variables showed a variance inflation factor lower than 1.3.

Table 4. Multiple regression analyses of the variables associated with weight and BMI changes during the lockdown period.

\begin{tabular}{ccccccc}
\hline \multirow{2}{*}{ Variable } & \multicolumn{3}{c}{ Weight Change } & \multicolumn{3}{c}{ BMI Change } \\
\cline { 2 - 7 } & $\boldsymbol{\beta}$ & $\mathbf{9 5 \% \mathbf { C I }}$ & $\boldsymbol{p}$ & $\boldsymbol{\beta}$ & $\mathbf{9 5 \% \mathbf { C I }}$ & $\boldsymbol{p}$ \\
\hline Secondary schools/graduation & -1.15 & $-2.13,-0.17$ & 0.022 & -0.46 & $-0.83,-0.09$ & 0.016 \\
None/lower exercise & 0.25 & $-0.97,1.47$ & 0.69 & 0.04 & $-0.41,0.49$ & 0.88 \\
Boredom/solitude & 0.004 & $-1.04,1.04$ & 0.99 & -0.003 & $-0.39,0.39$ & 0.99 \\
\hline Anxiety/depression & 1.61 & $0.53,2.69$ & 0.004 & 0.60 & $0.19,1.01$ & 0.004 \\
Increased eating & 0.78 & $-0.49,2.05$ & 0.23 & 0.29 & $-0.18,0.76$ & 0.24 \\
\hline Not consuming healthy foods & 1.48 & $0.19,2.77$ & 0.026 & 0.59 & $0.10,1.08$ & 0.019 \\
Usual/higher sweets & 0.93 & $-0.29,2.15$ & 0.14 & 0.38 & $-0.07,0.83$ & 0.10 \\
\hline
\end{tabular}

Lower education level, self-reported anxiety/depression, and not consuming healthy foods were significantly associated with increased weight and BMI gain during the lockdown period.

To evaluate whether not-healthy food choices could mediate the effects of self-reported anxiety/depression on weight gain, a regression path model was applied. In the presence of self-reported anxiety/depression, the estimated weight gain was $2.69 \mathrm{~kg}(95 \% \mathrm{CI} 1.66-3.71 ; p<0.001)$; the estimated direct effect of anxiety/depression was $2.07 \mathrm{~kg}(95 \% \mathrm{CI} 1.07-3.07 ; p<0.001)$, while the indirect effect linked to unhealthy choices accounted for $0.62 \mathrm{~kg}(95 \%$ CI $0.16-1.08 ; p=0.008)$. 


\section{Discussion}

We found that patients with obesity attending an Obesity Unit in Northern Italy showed a $\approx 1.5 \mathrm{~kg}$ self-reported weight gain after the first month of lockdown. Lower education level, self-reported anxiety/depression, and not paying attention to the healthiness of food choices were significantly associated with weight and BMI increase.

Italy was the first European country to be deeply affected by the Covid-19 pandemic and to undertake severe restrictive measures at a national level. This implied a greater risk of sedentarism and exercise reduction on one side, but on the other, an increased possibility to eat almost every meal at home, the impossibility to consume restaurant/cafeteria meals, and the availability of more time to cook, with lower need for ready meals, usually rich in fats, sugars, and salt. Accordingly, most of our patients showed a reduction both in their exercise level and, likely, in physical activity during work, as only $15 \%$ continued to go to the workplace during quarantine. Indeed, even though all our patients received personalized nutritional advice and on average have been attending our unit for six months, they reported many unhealthy dietary habits, such eating more (40\%), not paying attention to the healthiness of the consumed food (28\%), consuming more sweets (50\%), more snacks $(33 \%)$, more frozen/canned foods (17\%), and less fruit and vegetables than before (18\%). Among those, not paying attention to the healthiness of food was the behavior most strongly associated with weight gain, with a more than 50\% increased risk. In Italian children and adolescents with obesity, unfavorable changes in eating, sleep, and activity behaviors occurred during the lockdown period with the school closure [15]. No data about their weight changes were available. Thus, these were the first available data about changes in nutritional habits and weight during the current quarantine.

Low education might be a proxy for low socioeconomic level, a condition potentially impacting on food choice (greater purchase of more shelf-stable, highly processed foods at the expense of less processed, less energy-dense, fresh, perishable foods which are usually more expensive). Indeed, the increased social isolation, loneliness, boredom, anxiety, and depression generated by the pandemic might have played major roles in the lifestyle changes. In particular, self-reported anxiety/depression was the strongest predictor of weight gain in our patients. It is well known that emotional changes and mood disorders influence food choices, with the search for comfort foods, such as processed snacks and sweets [16-18]. An increased rate of depression and anxiety disorders has been described during the COVID-19 pandemic [5-10]. The anxiety/depression reported by our patients was strongly associated with weight gain and resulted in being the more relevant factor in predicting increase in body weight, after adjusting for consuming unhealthy foods.

These data suggest the pressing need to provide individuals with obesity-particularly those more vulnerable individuals_-with tools, such as telemedicine instruments, to offer lifestyle information and interventions, and psychological support and guidance to maintain healthy choices, also in consideration of the uncertainty of the quarantine duration.

Furthermore, individuals with obesity are at increased risk of either chronic or acute diseases, including COVID-19 infection and complications, as suggested by growing evidence [19-21]. The increased risk is due to multiple factors [21]; in particular, excess ectopic fat might reduce both protective cardiorespiratory reserves, as well as potentiate the immune dysregulation and pro-inflammatory response, and have detrimental effects on lung function [22,23]. Finally, the consumption of unhealthy diets has been proposed to adversely impact on susceptibility to COVID-19 and recovery [24,25].

Increasing weight might be a vicious circle leading to increased infection risk so that, now, obesity and COVID-19 infection can be considered two public healthy pandemics colliding [4].

The present study had several limitations. The retrospective design of the study allowed us to estimate associations only and the sample size was small. Weight was self-reported and not measured; similarly, self-reported questionnaires were used. Those data may have been affected by bias and low reliability. Ad-hoc psychometric questionnaires were not employed. Anxiety and depression were combined in the same item. Other potential confounders have not been examined. The majority of our 
patients were women; however, the same gender distribution was reported by most published studies on outpatients as well [26-28].

Indeed, our results were consistent; our sample size $(n=150)$ achieved a $91 \%$ power with a significance level (alpha) of 0.05 to evaluate the associations with weight changes. This was the first study analyzing weight and dietary changes in adults during the lockdown period.

\section{Conclusions}

A small cohort of individuals with obesity significantly gained weight 1 month after the beginning of the lockdown period. The adverse mental burden linked to the COVID-19 pandemic might be associated with their increased weight. Further larger studies on this topic are needed to confirm these preliminary results obtained in a limited number of patients.

Author Contributions: Conceptualization, S.B. (Simona Bo), M.P. and V.P.; methodology, S.B. (Simona Bo), M.P., and V.P.; formal analysis, S.B. (Simona Bo) and R.R.; investigation, M.P., V.P., E.S., I.G., S.B. (Sara Belcastro), C.C., A.B., F.D.M., E.G. and F.B.; writing-original draft preparation, S.B. (Simona Bo); writing-review and editing, S.B. (Simona Bo), M.P., V.P., E.S., I.G., C.C., A.B., S.B. (Sara Belcastro), F.D.M, E.G. and F.B. All authors have read and agreed to the published version of the manuscript.

Funding: This research received no external funding.

Acknowledgments: We are grateful to Paola Scuntero, Patrizia La Perna, Stefania Piccirillo, Nadia Lobina for their precious work at our Obesity Unit.

Conflicts of Interest: The authors declare no conflict of interest.

\section{References}

1. Maestra, S.L.; Abbondandolo, A.; Flora, S.D. Epidemiological trends of COVID-19 epidemic in Italy during March 2020. From 1,000 to 100,000 cases. J. Med. Virol. 2020. [CrossRef]

2. Gazzetta Ufficiale. Available online: https://www.gazzettaufficiale.it/eli/id/2020/03/09/20A01558/sg (accessed on 13 April 2020).

3. Gatto, M.; Bertuzzo, E.; Mari, L.; Miccoli, S.; Carraro, L.; Casagrandia, R.; Rinaldo, A. Spread and dynamics of the COVID-19 epidemic in Italy: Effects of emergency containment measures. Proc. Natl. Acad. Sci. USA 2020, 202004971. [CrossRef] [PubMed]

4. Ryan, D.H.; Ravussin, E.; Heymsfield, S. COVID 19 and the patient with obesity-The editors speak out. Obesity 2020, 28, 847. [CrossRef]

5. Huang, Y.; Zhao, N. Generalized anxiety disorder, depressive symptoms and sleep quality during COVID-19 outbreak in China: A web-based cross-sectional survey. Psychiatry Res. 2020, 288, 112954. [CrossRef]

6. Sønderskov, K.M.; Dinesen, P.T.; Santini, Z.I.; Østergaard, S.D. The depressive state of Denmark during the COVID-19 pandemic. Acta Neuropsychiatr. 2020, 1-3. [CrossRef]

7. Wang, C.; Pan, R.; Wan, X.; Tan, Y.; Xu, L.; Ho, C.S.; Ho, R.C. Immediate psychological responses and associated factors during the initial stage of the 2019 Coronavirus Disease (COVID-19) epidemic among the general population in China. Int. J. Environ. Res. Public Health 2020, 17, 1729. [CrossRef] [PubMed]

8. Liang, L.; Ren, H.; Cao, R.; Hu, Y.; Qin, Z.; Li, C.; Mei, S. The effect of COVID-19 on youth mental health. Psychiatr. Q. 2020. [CrossRef]

9. Moccia, L.; Janiri, D.; Pepe, M.; Dattoli, L.; Molinaro, M.; De Martin, V.; Chieffo, D.; Janiri, L.; Fiorillo, A.; Sani, G.; et al. Affective temperament, attachment style, and the psychological impact of the COVID-19 outbreak: An early report on the Italian general population. Brain Behav. Immun. 2020, 87, 75-79. [CrossRef]

10. Rajkumar, R.P. COVID-19 and mental health: A review of the existing literature. Asian J. Psychiatr. 2020, 52, 102066. [CrossRef]

11. Thomson, B. The COVID-19 pandemic: A global natural experiment. Circulation 2020. [CrossRef]

12. Balanzá-Martínez, V.; Atienza-Carbonell, B.; Kapczinski, F.; Boni, R.B.D. Lifestyle behaviours during the COVID-19-Time to connect. Acta Psychiatr. Scand. 2020. [CrossRef]

13. Rundle, A.G.; Park, Y.; Herbstman, J.B.; Kinsey, E.W.; Wang, Y.C. COVID-19-related school closings and risk of weight gain among children. Obesity 2020. [CrossRef] 
14. American Psychiatric Association. Diagnostic and Statistical Manual of Mental Disorders (DSM-5), 5th ed.; American Psychiatric Association: Washington, DC, USA, 2013.

15. Pietrobelli, A.; Pecoraro, L.; Ferruzzi, A.; Heo, M.; Faith, M.; Zoller, T.; Antoniazzi, F.; Piacentini, G.; Fearnbach, S.N.; Heymsfield, S.B. Effects of COVID-19 lockdown on lifestyle behaviors in children with obesity living in Verona, Italy: A longitudinal study. Obesity 2020. [CrossRef] [PubMed]

16. Macht, M. Characteristics of eating in anger, fear, sadness and joy. Appetite 1999, 33, 129-139. [CrossRef] [PubMed]

17. Anton, S.D.; Miller, P.M. Do negative emotions predict alcohol consumption, saturated fat intake, and physical activity in older adults? Behav. Modif. 2005, 29, 677-688. [CrossRef] [PubMed]

18. Macht, M. How emotions affect eating: A five-way model. Appetite 2008, 50, 1-11. [CrossRef] [PubMed]

19. Muscogiuri, G.; Pugliese, G.; Barrea, L.; Savastano, S.; Colao, A. Obesity: The "Achilles heel" for COVID-19? Metabolism 2020, 108, 154251. [CrossRef]

20. Kalligeros, M.; Shehadeh, F.; Mylona, E.K.; Benitez, G.; Beckwith, C.G.; Chan, P.A.; Mylonakis, E. Association of obesity with disease severity among patients with COVID-19. Obesity 2020. [CrossRef]

21. Ryan, P.M.; Caplice, N.M. Is adipose tissue a reservoir for viral spread, immune activation and cytokine amplification in COVID-19. Obesity 2020. [CrossRef]

22. Sattar, N.; McInnes, I.B.; McMurray, J.J.V. Obesity a risk factor for severe COVID-19 infection: Multiple potential mechanisms. Circulation 2020. [CrossRef]

23. Malavazos, A.E.; Romanelli, M.M.C.; Bandera, F.; Iacobellis, G. Targeting the adipose tissue in COVID-19. Obesity 2020. [CrossRef] [PubMed]

24. Butler, M.J.; Barrientos, R.M. The impact of nutrition on COVID-19 susceptibility and long-term consequences. Brain Behav. Immun. 2020, 87, 53-54. [CrossRef] [PubMed]

25. Naja, F.; Hamadeh, R. Nutrition amid the COVID-19 pandemic: A multi-level framework for action. Eur. J. Clin. Nutr. 2020. [CrossRef]

26. Agnoli, C.; Sieri, S.; Ricceri, F.; Giraudo, M.T.; Masala, G.; Assedi, M.; Panico, S.; Mattiello, A.; Tumino, R.; Giurdanella, M.C.; et al. Adherence to a Mediterranean diet and long-term changes in weight and waist circumference in the EPIC-Italy cohort. Nutr. Diabetes 2018, 8, 22. [CrossRef]

27. Bertoli, S.; Leone, A.; Vignati, L.; Bedogni, G.; Martínez-González, M.A.; Bes-Rastrollo, M.; Spadafranca, A.; Vanzulli, A.; Battezzati, A. Adherence to the Mediterranean diet is inversely associated with visceral abdominal tissue in Caucasian subjects. Clin. Nutr. 2015, 34, 1266-1272. [CrossRef] [PubMed]

28. Sasdelli, A.S.; Petroni, M.L.; Delli Paoli, A.; Collini, G.; Calugi, S.; Dalle Grave, R.; Marchesini, G. Expected benefits and motivation to weight loss in relation to treatment outcomes in group-based cognitive-behavior therapy of obesity. Eat. Weight Disord. 2018, 23, 205-214. [CrossRef] 